\title{
New Representatives of «Nonuniform» Naphthophosphacyclophanes Based on 1,3-Dihydroxynaphthalene
}

\author{
Pavel V. Slitikov, ${ }^{a}$ and Alexander G. Martynov ${ }^{\mathrm{b}}$ \\ aBauman Moscow State Technical University, 105005 Moscow, Russian Federation \\ ${ }^{\mathrm{b}}$ Institute of Physical Chemistry and Electrochemistry, Russian Academy of Sciences, 119071 Moscow, Russian Federation \\ ${ }^{\circledR}$ Corresponding authorE-mail: pavlasiy@mail.ru
}

The method of molecular assembling was used to synthesize new representatives of «nonuniform» naphthophosphacyclophanes containing the fragment of 1,3-dihydroxynaphthalene. Some physicochemical characteristics of the obtained compounds are studied and their conformational features are discussed.

Keywords: Dihydroxynaphthalenes, phosphorylation, naphthophosphacyclophanes.

\section{Новые преАставители "неоднородных" нафтофосфациклофанов на основе 1,3-дигидроксинафталина}

\author{
П. В. Слитиков, ${ }^{\mathrm{a}}$ А. Г. Мартынов ${ }^{\mathrm{b}}$ \\ ${ }^{\mathrm{a}}$ Московский государственный технический университет им. Н.Э. Баумана, 105005 Москва, Россия \\ 'Институт физической химии и электрохимии им. А.Н. Фрумкина РАН, 119071 Москва, Россия \\ ${ }^{\circledR}$ E-mail: pavlasiy@mail.ru
}

\begin{abstract}
Методоммолекулярной сборки синтезированы новые представители «неоднородных» нафтофосфаииклофанов, содержащих в своей структуре фрагмент 1,3-дигидроксинафталина. Изучены некоторые физико-химические характеристики полученных веществ и рассмотрены их конформационные особенности.
\end{abstract}

Ключевые слова: Дигидроксинафталины, фосфорилирование, нафтофосфациклофаны.

Design of novel macroheterocyclic compounds is an important task from the viewpoint of their wide applications. Among various building blocks for macroheterocycles naphthalenes attract special attention. Up to date, various naphthophosphacyclophanes based on dihydroxynaphthalenes with spatially separated hydroxyl groups have been synthesized, ${ }^{[1]}$ but application of 1,3-dihydroxynaphthalene (naphthoresorcinol) for the synthesis of such systems is less studied..$^{[2]}$ However, naphthoresorcinol is widely used in the synthesis of crown ethers and polymers, ${ }^{[3]}$ its derivatives reveal biological activity. ${ }^{[4]}$

The present work aimed to synthesize and study properties of «nonuniform» naphthophosphacyclophanes, based on the fragment of 1,3-dihydroxynaphthalene $\mathbf{1}$. The arrangement of substituents in the starting building block can provide conformationally rigid macrocycles, which is particularly important from the viewpoint of further elab- oration of supramolecular assemblies and catalytic systems.

Naphthophosphacyclophanes were synthesized according to the Scheme 1. Diamidophosphite $2^{[2]}$ was synthesized by phosphorylation of $\mathbf{1}$ with hexaethyltriamidophosphite (HETA). ${ }^{[5]}$ Molecular assembling of $\mathbf{2}$ was performed either with asymmetrical 1,7-dihydroxynaphthalene $\mathbf{3}$ or symmetrical 2,7-dihydroxynaphthalene 4. Reactions were performed in acetonitrile, which provided optimal reaction rates. ${ }^{[6]}$

Cyclophosphorylated products $\mathbf{5}$ and $\mathbf{6}$ were isolated in good yields $(\sim 70 \%)$, their structure was confirmed by ${ }^{1} \mathrm{H}$, ${ }^{13} \mathrm{C},{ }^{31} \mathrm{P}$ NMP spectroscopy, MALDI TOF mass-spectrometry and elemental analysis. ${ }^{[7]}$ Notably, the symmetrization of $\mathbf{5}$ and $\mathbf{6}$ with the possible formation of the uniform cyclophanes was not observed upon storage of their solutions.

Sulfurization of cyclophanes $\mathbf{5}$ and $\mathbf{6}$ was performed by reactions with sulfur in dichloromethane, ${ }^{[8]}$ correspond- 


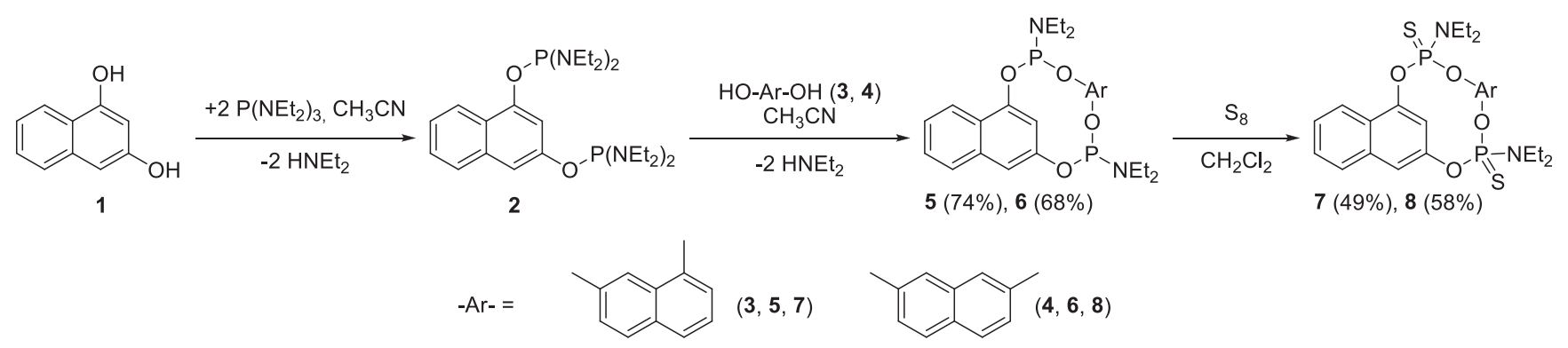

Scheme 1. Synthesis of nonuniform cyclophanes based on 1,3-dihydroxynaphthalene.

ing thionphosphates 7 and $\mathbf{8}$ were isolated as oils in $\sim 50 \%$ yields after column chromatography.

One could expect, that cyclophosphorylation of 1,7-dihydroxynaphthalene 3 could result in formation of two structural isomers with sequential (1',3:1,7'-isomer, $\mathbf{5 A}$ ) or pairwise (1',1:3,7'-isomer, 5B) connection of the naphthalene radicals (Figure 1). However, similarly to the previously studied uniform systems based on asymmetrical 1,6and 1,3-dihydroxynaphthalenes, ${ }^{[1 \mathrm{c}, 2]}$ in the present study we could isolate only one structural isomer $\mathbf{5 A}$ with the sequential connection of hydroxyl-groups in the macrocycle.
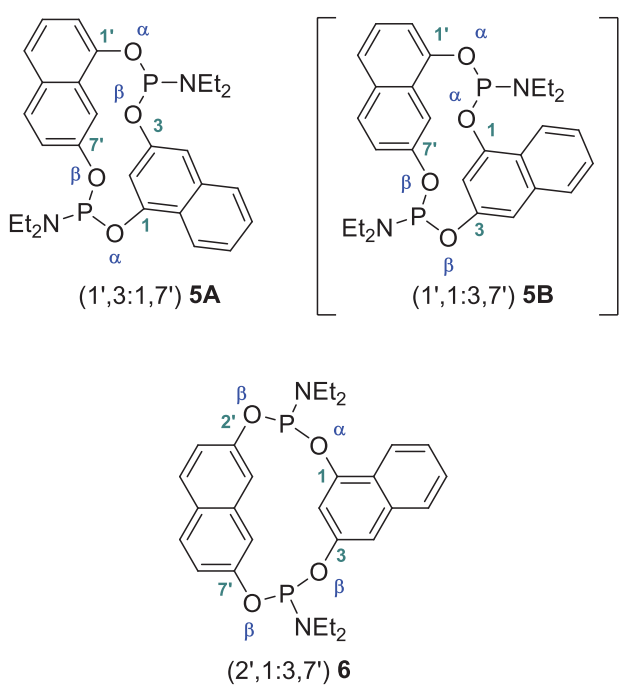

Figure 1. Numbering in two isomers of cyclophane 5 and cyclophane $\mathbf{6}$.

First of all, the formation of one isomer was supported by thin-layer chromatography of the reaction mixture, exhibiting single spot of the product in various eluents. Previously, on the example of the uniform naphthophosphacyclophane, based on 1,7-dihydroxynaphthalene, the formation of two isomers - (1',7:1,7' and 1',1:7,7') was observed. These isomers were found to have different physical-chemical and spectral properties. ${ }^{[9]}$

Single sets of signals were observed in ${ }^{1} \mathrm{H}$ and ${ }^{13} \mathrm{C}$ NMR spectra of $\mathbf{5}$, suggesting the formation of one isomer. In its ${ }^{31} \mathrm{P}$ NMR spectrum there was observed only one signal which is in line with the connection of each phosphorus atom with oxygen atom in $\alpha$ - and $\beta$-positions of naphthalene systems in $\mathbf{5 A}$, which makes them virtually equivalent. In the case of cyclophane $\mathbf{6}$ phosphorus atoms are in different surrounding $(\alpha-\mathrm{O}, \beta-\mathrm{O}$ and $\beta-\mathrm{O}, \beta-\mathrm{O})$, therefore two signals are observed in its ${ }^{31} \mathrm{P}$ NMR spectrum. ${ }^{[1]}$ This feature is preserved in thione derivatives $\mathbf{7}$ and $\mathbf{8}$.

We attempted to explain the regioselectivity of cyclophosphorylation of 1,7-dihydroxynaphthalene $\mathbf{3}$ with diamidophosphite 2 using thermochemical recipe $\mathrm{T}^{[10]}$ implemented in SPARTAN'14 package (www.wavefun. com). T1 reproduces heats of formation obtained from the highly accurate but time-consuming G3(MP2) model, which in turn closely reproduces experimental heats. T1 recipe was designed to deal with conformationally flexible molecules and it affords 2-3 orders of magnitude less computation time in comparison with G3(MP2). Due to these benefits this method was widely used previously for prediction and interpretation of reactivity of various organic compounds. ${ }^{[1]}$

Using this method, we determined the heats of formation of lowest energy conformations for both starting compounds $\mathbf{2}$ and $\mathbf{3}$, acyclic intermediate molecules and isomers 5A and 5B (Figure 2). Calculation of $\Delta_{f} E$ for each reaction pathway evidenced that the most energetically favourable intermediate is formed via nucleophilic attack of 1'-OH group in $\mathbf{3}$ to $\mathrm{P}\left(\mathrm{NEt}_{2}\right)_{2}$ group attached to 3-O in 2. Inevitably, cyclization of this intermediate affords the isomer of cyclophane $\mathbf{5 A}$ as the more stable product which is in line with the experimental results. The calculated mean planes formed by naphthalene systems form dihedral angles $79^{\circ}$ and $41^{\circ}$ in the case of low-energy conformers of $\mathbf{5}$ and $\mathbf{6}$, respectively (Figure 3), suggesting more efficient overlap between aromatic systems of naphthalene units in the later case.

Therefore, in the present work there were synthesized and characterized four novel naphthophosphacyclophanes based on 1,3- and 1,7- or 2,7-dihydroxynaphthalenes (5, 7 and 6, 8, respectively). Thermochemical recipe T1 was firstly used to rationalize regioselectivity in the reactions of formation of nonuniform cyclophane $\mathbf{5}$ constructed of two asymmetric dihydroxynaphthalenes. These results suggest that the application of this thermochemical recipe might be beneficial for interpretation of reactivity in synthesis of conformationally labile macrocyclic systems.

\section{Notes and References}

1. (a) Slitikov P.V., Evdokimenkova Yu.B., Rasadkina E.N., Vasyanina L.K., Nifantiev E.E. Macroheterocycles 2011, 4, 311-323; 


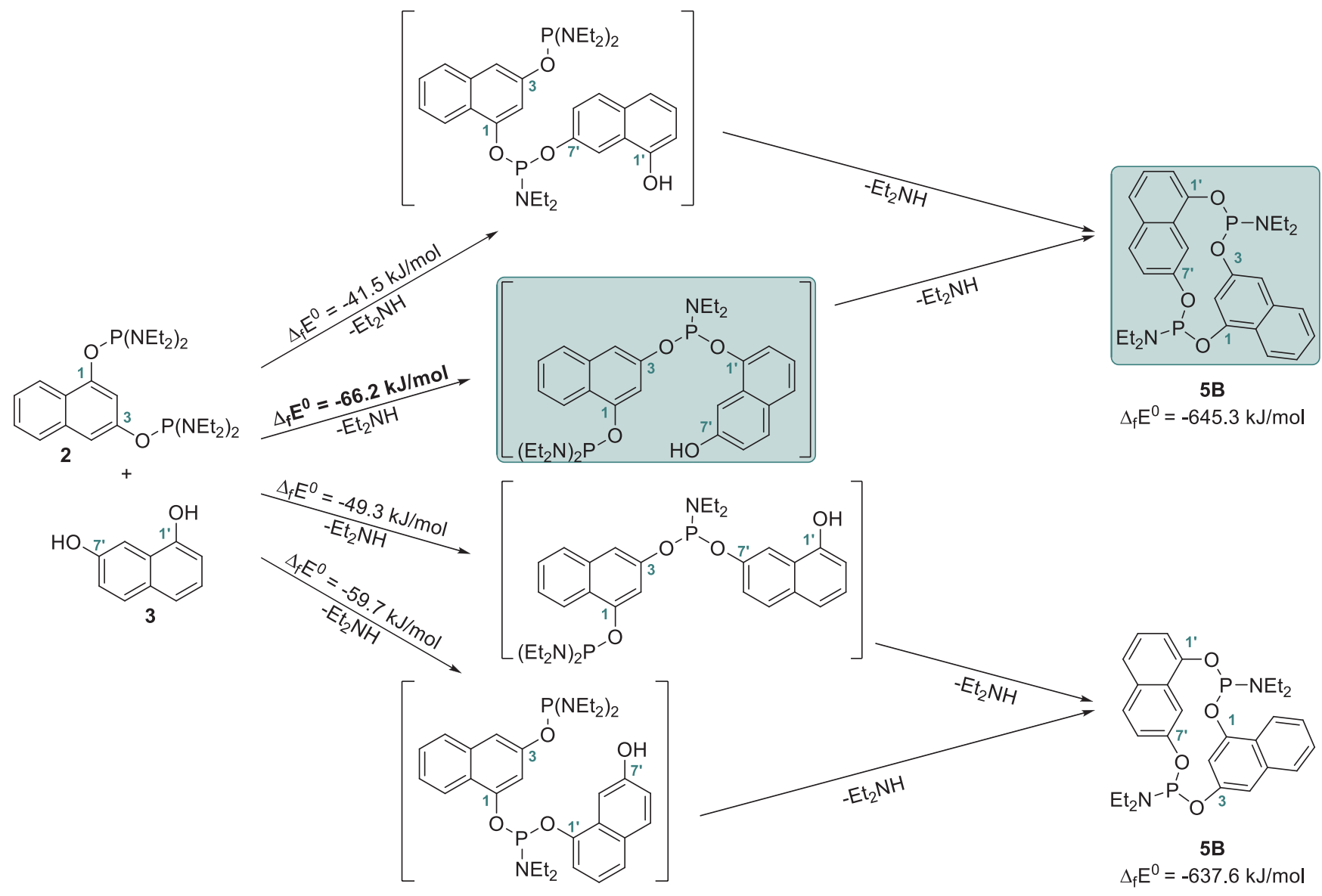

Figure 2. Energetic pathway of cyclophosphorylation of $\mathbf{3}$ with $\mathbf{2}$ according to T1 thermochemical recipe.

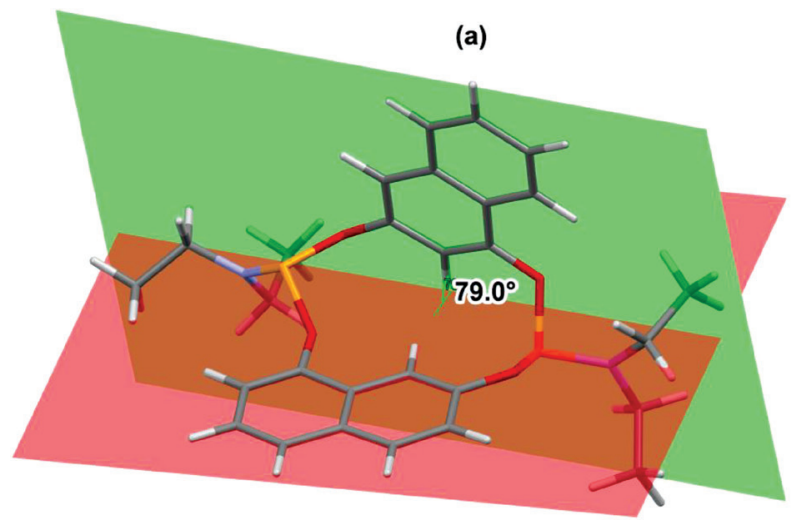

(b)

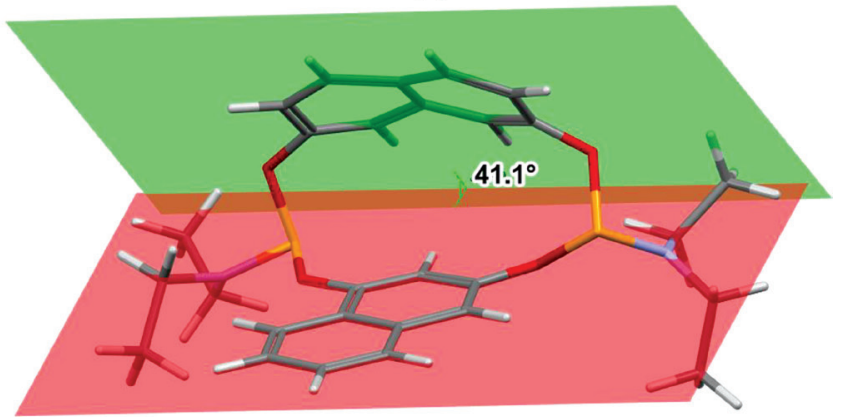

Figure 3. Geometry of T1-optimized low-energy conformers of cyclophanes $\mathbf{5}$ (a) and $\mathbf{6}$ (b).

(b) Slitikov P.V., Rasadkina E.N., Vasyanina L.K., Nifantiev E.E. Macroheterocycles 2013, 6, 170-179; (c) Slitikov P.V., Rasadkina E.N., Vasyanina L.K., Nifantiev E.E. Russ. Chem. Bull. 2013, 62, 2023-2031.

2. Rasadkina E.N., Slitikov P.V., Pechkina M.P., Vasyanina L.K., Stash A.I., Nifantiev E.E. Russ. J. Gen. Chem. 2005, 75, 1910-1918.

3. Wagner-Wysiecka E., Luboch E., Marczak B., Biernat J.F. Pol. J. Chem. 2001, 75, 1457-1463.

4. (a) Solterman A.T., Luiz M., Biasutti M.A., Carrascoco M., Amat-Guerri F., Garcia N.A. J. Photochem. Photobiol., A 1999, 129, 25-32; (b) Gard R.K., Pardeep K., Ram R.S.,
Zaidi Z.H. Spectrosc. Lett. 2001, 34, 685-700; (c) Simpson T.J., Bandumathie Weerasooriya M.K. J. Chem. Soc., Perkin Trans. 1 2000, 2771-2775; (d) Hsiao S.-H., Guo W., Chuhg C.-L., Chen W.-T. Eur. Polymer J. 2010, 46, 1878-1890.

5. Noth H., Vetter H.J. Chem. Ber. 1965, 98, 1981-1987.

6. All syntheses were conducted in dry solvents under an argon atmosphere. ${ }^{1} \mathrm{H},{ }^{13} \mathrm{C}$ and ${ }^{31} \mathrm{P} \mathrm{NMR}$ spectra (in $\mathrm{CDCl}_{3}$ ) were recorded on a JEOL ECX-400 spectrometer operating at 400, 100.5 and $161.8 \mathrm{MHz}$, respectively; chemical shifts ( $\delta$, ppm) were referenced to TMS $\left({ }^{1} \mathrm{H}\right.$ and $\left.{ }^{13} \mathrm{C}\right)$ or to $85 \% \mathrm{H}_{3} \mathrm{PO}_{4}\left({ }^{31} \mathrm{P}\right)$. Spin-spin coupling constants $(J)$ are given in hertzs $(\mathrm{Hz})$. Mass spectra were measured on a Bruker Ultraflex MALDI-TOF 
spectrometer using a nitrogen laser $(\lambda 337 \mathrm{~nm})$ and trihydroxyanthracene as a matrix. Column adsorption chromatography was operated on silica gel L 100/250; TLC was performed on Silufol plates (UV-254) using $\mathrm{C}_{6} \mathrm{H}_{6}$-dioxane, 5:1. Detection was achieved using iodine vapor treatment and calcination.

7. 3,7-Bis(diethylamidate)-1,5-dinaphthalina-2,4,6,8-tetraoxa-3,7-diphosphacyclooctaphane (general procedure). A solution $0.160 \mathrm{~g}(1 \mathrm{mmol})$ of 1,3-dihydroxynaphthalene 1 in $6 \mathrm{ml}$ of acetonitrile was added with stirring at room temperature

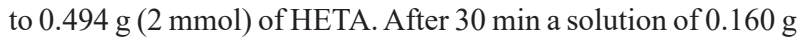
(1 mmol) of 1,7-(3) or 2,7-(4) dihydroxynaphthalene in $4 \mathrm{ml}$ of acetonitrile was added to reaction mixture. The mixture was stirred for $4 \mathrm{~h}$ and left for $20 \mathrm{~h}$. The remaining oily precipitate was washed twice with acetonitrile and dried in vacuum for $2 \mathrm{~h}\left(1 \mathrm{mmHg}, 60^{\circ} \mathrm{C}\right)$.

3,7-Bis(diethylamidate)-1(1,3),5(1,7)-dinaphthalina-2,4,6,8tetraoxa-3,7-diphosphacyclooctaphane (5). Yield $0.77 \mathrm{~g}$ (74 \%). Oily substance. $\mathrm{R}_{f} 0.69 .{ }^{1} \mathrm{H}$ NMR $(296 \mathrm{~K}) \delta_{\mathrm{H}}$ ppm: 1.02 $\left(12 \mathrm{H}, \mathrm{t}, \mathrm{CH}_{3}, 3 \mathrm{~J}_{\mathrm{HH}}=4.1\right), 3.23\left(8 \mathrm{H}\right.$, br.m, $\left.\mathrm{CH}_{2}-\mathrm{N},{ }^{3} J_{\mathrm{PH}}=8.4 ; 9.2\right)$, 7.17-7.67 (10H, br.m, CH), $7.90\left(1 \mathrm{H}\right.$, br.d, $\left.\mathrm{CH}^{8^{\prime}}\right), 8.09$ (1H, br.d, $\left.\mathrm{CH}^{8}\right) .{ }^{13} \mathrm{C}$ NMR $\delta_{\mathrm{C}}$ ppm: $14.6\left(\mathrm{CH}_{3}\right), 37.9\left(\mathrm{~d}, \mathrm{CH}_{2},{ }^{2} J_{\mathrm{PC}}=22.1\right)$, $108.7\left(\mathrm{C}^{2} \mathrm{H}\right), 109.9\left(\mathrm{~d}, \mathrm{C}^{2,4^{\prime}} \mathrm{H}\right), 113.6\left(\mathrm{~d}, \mathrm{C}^{8} \mathrm{H}\right), 121.6\left(\mathrm{~d}, \mathrm{C}^{6} \mathrm{H}\right)$, $122.1\left(\mathrm{~d}, \mathrm{C}^{4,5^{7}} \mathrm{H}\right), 124.0\left(\mathrm{C}^{5,8^{\prime}} \mathrm{H}\right), 126.8\left(\mathrm{C}^{3,7^{7}} \mathrm{H}\right), 128.1\left(\mathrm{C}^{6} \mathrm{H}\right)$, $129.2\left(\mathrm{C}^{9}\right), 131.2\left(\mathrm{C}^{9}\right), 134.8\left(\mathrm{C}^{10,10^{\circ}}\right), 149.1\left(\mathrm{~d}, \mathrm{C}^{1} \mathrm{O}\right), 151.4$ $\left(\mathrm{d}, \mathrm{C}^{7,1^{\prime} 3^{\prime}} \mathrm{O}\right) .{ }^{31} \mathrm{P}$ NMR $(296 \mathrm{~K}) \delta_{\mathrm{p}} \mathrm{ppm}: 140.2 . \mathrm{m} / z$ (MALDI) 522.68. $\mathrm{C}_{28} \mathrm{H}_{32} \mathrm{~N}_{2} \mathrm{O}_{4} \mathrm{P}_{2}$ requires 522.51. 3,7-Bis(diethylamidate)1(1,3),5(2,7)-dinaphthalina-2,4,6,8-tetraoxa-3,7-diphosphacyclooctaphane (6). Yield $0.71 \mathrm{~g}(68 \%)$. Mp $125-127{ }^{\circ} \mathrm{C} . \mathrm{R}_{f}$ 0.59. ${ }^{1} \mathrm{H}$ NMR $(296 \mathrm{~K}) \delta_{\mathrm{H}}$ ppm: $1.08\left(12 \mathrm{H}, \mathrm{t}, \mathrm{CH}_{3}\right), 3.25(8 \mathrm{H}$, br.m, $\left.\mathrm{CH}_{2}-\mathrm{N},{ }^{3} \mathrm{~J}_{\mathrm{PH}}=7.2 ; 9.1\right), 7.03\left(1 \mathrm{H}, \mathrm{s}, \mathrm{CH}^{2}\right), 7.15(2 \mathrm{H}, \mathrm{d}$, $\left.\mathrm{CH}^{3^{\prime}, 6^{\prime}},{ }^{3} J_{\mathrm{H}\left(3^{3}\right), \mathrm{H}\left(4^{4}\right)}={ }^{3} J_{\mathrm{H}\left(5^{5}\right), \mathrm{H}\left(6^{\prime}\right)}=10.5\right), 7.35\left(5 \mathrm{H}\right.$, br.m, $\left.\mathrm{CH}^{4,6,7,1^{1}, 8^{\prime}}\right)$, $7.65\left(3 \mathrm{H}, \mathrm{m}, \mathrm{CH}^{5,4^{\prime}, 5^{\prime}}\right), 8.11\left(1 \mathrm{H}, \mathrm{d}, \mathrm{CH}^{8},{ }^{3} \mathrm{~J}_{\mathrm{H}(\mathrm{7}) \mathrm{H}(8)}=8.3\right) .{ }^{31} \mathrm{P} \mathrm{NMR}$ $(296 \mathrm{~K}) \delta_{\mathrm{p}}$ ppm: 140.6, 141.1. Found: C 64.17, H 6.23, N 5.40, $\mathrm{P} 11.29 \% . \mathrm{C}_{28} \mathrm{H}_{32} \mathrm{~N}_{2} \mathrm{O}_{4} \mathrm{P}_{2}$ requires $\mathrm{C} 64.36, \mathrm{H} 6.18, \mathrm{~N} 5.36, \mathrm{P}$ $11.86 \%$.
8. Tionphosphoramidates (7, 8). (general procedure). Sulfur $0.032 \mathrm{~g}(1 \mathrm{mmol})$ was added to $0.261 \mathrm{~g}(0.5 \mathrm{mmol})$ of cyclophosphite $(\mathbf{5}, \mathbf{6})$ in $5 \mathrm{ml}$ of dichloromethane. The mixture was stirred for $3 \mathrm{~h}$ at room temperature and left for $24 \mathrm{~h}$. The solution was filtered, the solvent was evaporated in vacuum (12 $\mathrm{mmHg}$ ), and the residue was chromatographed on a column, the resulting product was eluted by the benzene-dioxane (10:1) system. The resulting material was dried in vacuum for $2 \mathrm{~h}\left(1 \mathrm{mmHg}, 70^{\circ} \mathrm{C}\right)$.

3,7-Bis(diethylamidate)-1(1,3),5(1,7)-dinaphthalina-2,4,6,8tetraoxa-3,7-diphospha-3,7-dithiacyclooctaphane (7). Yield $0.14 \mathrm{~g}(49 \%)$. Oily substance. $\mathrm{R}_{f} 0.71 .{ }^{1} \mathrm{H}$ NMR $(296 \mathrm{~K}) \delta_{\mathrm{H}}$ ppm: $0.98\left(12 \mathrm{H}, \mathrm{t}, \mathrm{CH}_{3}, 3_{\mathrm{HH}}=5.9\right), 3.11-3.24(8 \mathrm{H}$, br.m, $\left.\mathrm{CH}_{2}-\mathrm{N}\right), 6.90-8.00$ (12H, br.m, Ar). ${ }^{31} \mathrm{P}$ NMR $(296 \mathrm{~K}) \delta_{\mathrm{P}} \mathrm{ppm}$ : 66.6. Found: $\mathrm{P} 10.60 \%$. $\mathrm{C}_{28} \mathrm{H}_{32} \mathrm{~N}_{2} \mathrm{O}_{4} \mathrm{P}_{2} \mathrm{~S}_{2}$ requires $\mathrm{P} 10.56 \%$. 3,7-Bis(diethylamidate)-1(1,3),5(2,7)-dinaphthalina-2, 4,6,8tetraoxa-3,7-diphospha-3,7-ditiacyclooctaphane (8). Yield $0.17 \mathrm{~g}(58 \%)$. Oily substance. $\mathrm{R}_{f} 0.66 .{ }^{1} \mathrm{H}$ NMR $(296 \mathrm{~K}) \delta_{\mathrm{H}}$ ppm: $1.02\left(12 \mathrm{H}, \mathrm{t}, \mathrm{CH}_{3}\right), 3.18-3.33\left(8 \mathrm{H}\right.$, br.m, $\left.\mathrm{CH}_{2}-\mathrm{N}\right), 7.11$ $\left(1 \mathrm{H}, \mathrm{s}, \mathrm{CH}^{2}\right), 7.23\left(2 \mathrm{H}, \mathrm{d}, \mathrm{CH}^{3}, 6^{\prime},{ }^{3} J_{\mathrm{H}\left(3^{3}\right), \mathrm{H}\left(4^{4}\right)}={ }^{3} J_{\mathrm{H}\left(5^{\prime}\right) \mathrm{H}\left(6^{\prime}\right)}=9.7\right), 7.49$ $\left(5 \mathrm{H}, \mathrm{m}, \mathrm{CH}^{4,6,7,1^{\prime}, 8^{\prime}}\right), 7.80\left(4 \mathrm{H}, \mathrm{m}, \mathrm{CH}^{4.5,4^{\prime}, 5^{\prime}}\right), 8.16\left(1 \mathrm{H}, \mathrm{d}, \mathrm{CH}^{8}\right.$, $\left.{ }^{3} J_{\mathrm{H}(7) \mathrm{H}(8)}=8.8\right) .{ }^{31} \mathrm{P}$ NMR $(296 \mathrm{~K}) \delta_{\mathrm{P}} \mathrm{ppm}: 67.1,66.8 . \mathrm{m} / \mathrm{z}$ (MALDI) $587.58[\mathrm{M}+\mathrm{H}]^{+}$. $\mathrm{C}_{28} \mathrm{H}_{32} \mathrm{~N}_{2} \mathrm{O}_{4} \mathrm{P}_{2} \mathrm{~S}_{2}$ requires 586.61.

9. (a) Nifantyev E.E., Rasadkina E.N., Evdokimenkova Yu.B., Stash A.I., Belsky V.K., Vasyanina L.K. Heteroat. Chem. 2003, 14, 404-412; (b) Rasadkina E.N., Evdokimenkova Yu.B., Stash A.I., Belsky V.K., Vasyanina L.K., Nifantyev E.E. Russ. J. Gen. Chem. 2004, 74, 48-57.

10. (a) Cardillo P., Gigante L., Lunghi A., Fraleoni-Morgera A., Zanirato P. New J. Chem. 2008, 32, 47-53; (b) Guirado A., LópezCaracena L., López-Sánchez J.I., Sandoval J., Vera M., Bautista D., Gálvez J. Tetrahedron 2016, 72, 8055-8060; (c) Cardillo P., Dellavedova M., Gigante L., Lunghi A., Pasturenzi C., Salatelli E., Zanirato P. Eur. J. Org. Chem. 2012, 2012, 1195-1201.

11. Ohlinger W.S., Klunzinger P.E., Deppmeier B.J., Hehre W.J. J. Phys. Chem. A 2009, 113, 2165-2175. 